\title{
Analýza pohybu Homo neanderthalensis
}

\author{
Michaela Káčerková \\ Ústav antropologie, Př́rodovědecká fakulta, Masarykova univerzita, Kotlářská 267/2, 61137 Brno, Česká republika
}

Do redakce doručeno 16. února 2018; k publikaci přijato 19. června 2018

\section{LOCOMOTION ANALYSIS OF HOMO NEANDERTHALENSIS}

\begin{abstract}
The aim of this study is to evaluate the locomotion of Homo neanderthalensis and to compare the observed evidence with the locomotion of modern human (Homo sapiens). After a brief introduction to Neanderthal problematics follows the description of individual types of locomotion. Beside the environment, the possibilities of Neanderthal locomotion depend on the morphology of axial skeleton, namely the lumbar lordosis and the lordotic angle. The morphology of the upper and lower limb display its importance too. Upper limbs are considered with respect to manual dexterity, scraping and throwing. The morphology of the lower limbs influences walking and running, together with activities associated to movements of the knee and ankle joint.
\end{abstract}

KEY WORDS Neanderthals; locomotion; scraping; throwing; manual dexterity; walking; running

ABSTRAKT Cílem studie je zhodnotit možnosti lokomoce druhu Homo neanderthalensis a porovnat zjištěné skutečnosti s lokomocí moderního člověka (Homo sapiens). Po krátké charakteristice neandertálců následuje popis jednotlivých druhů lokomoce. Možnosti lokomoce neandertálců jsou (kromě prrírodních podmínek) závislé především na kostře osové (zde je důležitá bederní lordóza a s ní související lordotický úhel) a na morfologii horních a také dolních končetin. Horní končetiny jsou uvažovány v souvislosti s manuální zručností a se škrábáním a házením. Zmíněna je také jejich síla. Morfologie dolních končetin má vliv na chůzi a běh, činnosti spojené s pohybem kolenního a hlezenního kloubu.

KLÍČOVÁ SLOVA Neandertálci; lokomoce; škrábání; házení; manuální zručnost; chůze; běh

\section{ÚVOD}

Nejstarší nálezy fosilních pozůstatků neandertálců (Homo neanderthalensis) jsou datovány do doby před 130000 lety (Krapina v Chorvatsku a Saccopastore v Itálii), nejmladší pak do doby před 40000 - 35000 lety (Španělsko, Gibraltar). Neandertálci tedy obývali Evropu a Blízký východ přinejmenším 100000 let. Nejvyšší výskyt jejich pozůstatků tvoří skupina nalezišt ve Francii, dále pak v Chorvatsku, Španělsku nebo Itálii. V České republice se naleziště neandertálců nachází především na Moravě, v jeskyních Šipka, Švédův stůl a Kůlna. Jedná se o malé fragmenty lebky (Vančata 2003, 96).

Postkraniální skelet neandertálců byl velmi robustní, což se projevovalo především na kloubech a pravděpodobně to značilo větší množství svalové hmoty. Robustnost horních končetin naznačuje, že byly velmi silné a výkonné. Dolní končetiny byly zkrácené (vlivem zakřivení stehenní kosti a kratších bércových kostí), na jejich pohyblivost by to však nemělo mít žádný vliv. Neandertálci byli plně adaptovaní na bipední chůzi, měli rozvinutou podélnou i př́íčnou klenbu nohy. I přes jisté odlišnosti v morfologii ruky, byli schopni stejně přesného úchopu jako moderní člověk. Byli také schopni velmi silného stisku ruky (Trinkaus 1983, 368, 341; Niewoehner et al. 2003, 395).

\section{LOKOMOCE}

Neandertálci i moderní lidé jsou v důsledku předchozí evoluce samozřejmě plně bipední, nicméně morfologie neandertálců je velmi specifická. Zakř̌ivení bederní části jejich páteře se vymyká vzoru vývoje páteře v souvislosti s rozvojem bipedie jako hlavního způsobu pohybu. Bylo zjištěno, že 


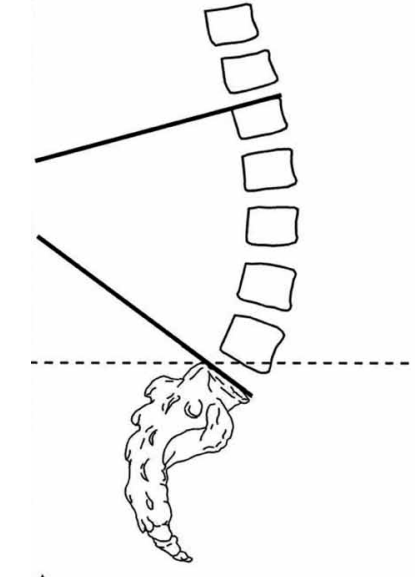

$\mathbf{A}$

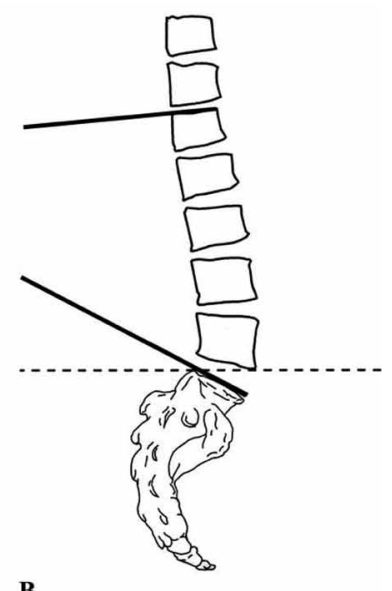

Obr. 1. Lordotický úhel u moderního člověka (A) a neandertálců (B). Upraveno podle: Been et al. 2012, 75 .

těla prvních čtyř bederních obratlů jsou zkosená ventrálně, zatímco u moderního člověka je běžné zkosení dorzálním směrem. Ventrální zkosení těl obratlů zapřičiňuje rovné až kyfotické zakřivení bederní části páteře (u moderních lidí naopak dorzální zkosení má za následek bederní lordózu). Lordotický úhel (obr. 1), definován jako úhel mezi horním okrajem těla prvního bederního obratle a horním okrajem křížové kosti (tělem prvního křížového obratle), byl tak u neandertálců menší než u všech ostatních homininů, ale větší než u lidoopů (Been et al. 2012, 64, 72). Funkční důvod menšího lordotického úhlu neandertálců není jasný, může například poskytovat výhodu při pohybu v kopcovitém terénu, protože u moderního člověka dochází v průběhu chůze do kopce $\mathrm{k}$ určitému narovnání bederní lordózy (Sparrey et al., 2014, s. 2). Závěrem prováděné analýzy bylo potvrzení předpokladu, že lordotické zakřivení bederní páteře byla morfologická změna, která se odehrála při vývoji vzprrímené postavy a bipedie jako hlavního způsobu pohybu. Neandertálci ale svými malými lordotickými úhly a odlišným zkosením těl bederních obratlů $\mathrm{z}$ tohoto trendu vybočují. Popisovaná morfologie neandertálců mohla být pozůstatkem morfologie jejich předpokládaných předků, Homo heidelbergensis (Been et al. 2012, 74).

Novější studie $\mathrm{v}$ podobě $3 \mathrm{D}$ rekonstrukce páteře jedince Kebara 2 shodně ukázala, že tento jedinec vykazoval vertikálnější orientaci kosti křižové, menší lordotické zakřrivení bederní části páteře a kyfotické zakřivení hrudní části páteře mírně menší než u moderního člověka. Podobná morfologie páteře byla pozorována také u jedinců Shanidar 3 a La Chapelle-aux-Saints 1 (Been et al. 2017, 248).

Hypolordotická páteř je výhodná při zvedání břemen, protože méně zakřivené obratle mohou snést větší kompresní zatížení. Nevýhodou tohoto postavení páteře je kratší délka kroku, pomalejší chůze a ventrálně nakloněný hrudník. Pokud by tedy toto držení těla bylo pro neandertálce typické, mohli by být lépe přizpůsobení $\mathrm{k}$ přenášení těžkých břemen a $\mathrm{k}$ náročnějším aktivitám horní poloviny těla (Been et al. 2017, 248).
Se vzpřímeným postojem a bipedií souvisí také udržování rovnováhy, které je zajištováno mimo jiné i strukturami vnitřního ucha. Základní úvahou je, že zvětšení předního a zadního polokruhovitého kanálku a s tím spojené uzavření funkčně důležitých blanitých kanálků vede k lepší schopnosti rozeznávání malých vertikálních rotací hlavy. Tyto rotace jsou charakteristické pro moderního člověka pohybujícího se větší rychlostí (například během) po nerovném přírodním terénu (Spoor et al. 2003, 159).

Přední a zadní polokruhovité kanálky jsou však u neandertálců menší než u moderních lidí. Pokud je tedy předpoklad spojení zvětšených polokruhovitých kanálků a svižné chůze správný, naznačuje to, že lokomoce neandertálců byla výrazně méně zaměřená na běh a všeobecnou hbitost než u moderních lidí. Otázkou však je, zda funkční morfologie celého postkraniálního skeletu neandertálců odpovídá tomu, že by mohli mít skutečně odlišné pohybové chování než moderní lidé (Spoor et al. 2003, 159, 160).

\section{POHYB HORNÍCH KONČETIN}

\section{Síla}

Síla, čili schopnost působit různou intenzitou na objekty ve vnějším světě, je důležitou složkou adaptace neandertálců. Ačkoliv svalová hmota nemusí být důležitá pro populace žijící $\mathrm{v}$ průmyslovém, mechanizovaném prostředí, pro technologicky omezenější populace středního paleolitu však ano. Síla se posuzuje dle objemu svalů, tedy dle velikosti ploch jejich odstupu a úponu na kostech. Síla svalů souvisí s obvyklými činnostmi a pravděpodobně také odráží genetické rozdíly mezi populacemi. Vzhledem k robustnímu skeletu a většímu rozvoji struktur sloužících $\mathrm{k}$ úponu nebo odstupu svalů se předpokládá, že neandertálci měli větší schopnost využít sílu svalů než moderní lidé (Churchill, Rhodes 2006, 458).

Maximální možná síla, která může být svalem vyvinuta, je př́mo úměrná jeho fyziologickému prŕínému průřezu spočtenému jako objem svalu děleno průměrnou délkou vlákna (Churchill, Rhodes 2006, 465). Odhaduje se, že při flexi loketního kloubu (prováděné $m$. biceps brachii a $m$. brachialis) byli neandertálští muži přibližně o $33 \%$ silnější než muži recentní (Euroamerické) populace moderního člověka, pro ženy to pak bylo o 45 \% více. Při extenzi loketního kloubu (zajištované $m$. triceps brachii) jsou rozdíly ještě patrnější. Neandertálci jsou silnější o $79 \% \mathrm{v}$ př́padě mužů a $96 \% \mathrm{v}$ případě žen (Churchill, Rhodes 2006, 466).

$\mathrm{U}$ neandertálců se předpokládá vysoký podíl masa $\mathrm{v}$ potravě a lov byl tedy důležitou součástí jejich života. Je také pravděpodobné, že neandertálci byli při lovu v blízkém kontaktu s kořistí a používali zbraně účinné při malých vzdálenostech. U masožravých živočichů, kteří musí svoji kořist fyzicky přemoci, je síla svalů a velikost těla důležitým faktorem při výběru kořisti a úspěšnosti lovu. Bylo zjištěno, že schopnost pronásledovat a ulovit kořist je ovlivněna řadou znaků, jedním $\mathrm{z}$ nich je právě síla rukou, potažmo předních končetin (Churchill, Rhodes 2006, 458). Zdá se tedy, že lov je jednou 
z nejvíce pravděpodobných činností, při které byli neandertálci díky své síle zvýhodněni proti moderním lidem (Churchill, Rhodes 2006, 467).

\section{Schopnost házení}

Lopatky neandertálců jsou velké, protáhlé a robustní. Kloubní jamka ramenního kloubu (cavitas glenoidalis) je vyšší, užší a také mělčí než u moderních lidí (Di Vincenzo et al. 2012, 274). Důležitý je výskyt sulcus dorsalis (sulcus axillaris teretis). Jedná se o žlábek, který se nachází u laterálního okraje lopatky na její dorzální ploše, zatímco u moderních lidí se nachází na ventrální ploše (sulcus ventralis, sulcus axillaris subscapularis). Existuje také přechodný typ „bisulcate“ (facies axillaris bisulcata), kde jsou přítomny oba žlábky. Tento typ se vyskytuje jak u neandertálců, tak u moderních lidí. U každé $\mathrm{z}$ těchto variant je různě velká plocha pro odstup $m$. teres $m i$ nor (malý sval oblý), který zajištuje zevní rotaci a pomocnou addukci pažní kosti. $\mathrm{V}$ prrípadě sulcus dorsalis je tato plocha největší, je tedy pravděpodobné, že neandertálci měli tento sval silněji vyvinutý a zevní rotace pažní kosti tedy byla pro ně důležitá (Aiello, Dean 1990, 356, 357).

Funkční rozdíly způsobené morfologií lopatky bývají dávány do souvislosti se zatížením při již zmíněné rotaci a abdukci pažní kosti, což jsou pohyby potřebné např́íklad pro lov pomocí házení zbraní na větší vzdálenosti (Di Vincenzo et al. 2012, 274). Nicméně podobná morfologie kloubní jamky ramenního kloubu (cavitas glenoidalis) byla pozorována také u post-neolitických populací moderního člověka, což její zmiňovanou souvislost $s$ házením zpochybňuje.

Morfologii podporující schopnost házení má také klíční kost. Její větší délka spolu s vysoko položenou lopatkou může neandertálcům poskytovat více síly při hodu. Předpokládá se však, že při házení jsou aktivovány svaly paže, hrudníku a ramene, a to více na dominantní straně. To vede $k$ asymetrii pravé a levé pažní kosti, což u neandertálců nebylo pozorováno. Je tedy nepravděpodobné, že by házení bylo jejich obvyklou činností (Shaw et al. 2012, 2).

\section{Škrábání}

Velmi robustní diafýza, asymetrie příčného průřezu nebo větší pevnost v torzi a ohybu jsou vlastnosti pažní kosti, které jsou u neandertálců a moderních lidí rozdílné. Jednou z hypotéz vysvětlující tuto morfologii je lov pomocí zbraní účinných na krátké vzdálenosti. Je prokázáno, že diafýzy dlouhých kostí reagují na zatížení zvýšenou tvorbou kostní hmoty v rovině deformace a vzniká tak asymetrie příčného průřezu kosti (Shaw et al. 2012, 1).

Další z hypotéz naznačuje, že morfologie pažní kosti neandertálců může odrážet funkčně specifické a pravděpodobně se opakující pohyby rukou jako např́klad při výrobě ostrých kamenných nástrojů pro lov nebo při zpracování kůže. Pro neandertálce žijící v proměnlivém, chladnějším klimatu, $s$ potřebou lovu, konzumace masa a také přiměřeného oděvu, jsou tyto činnosti nezbytné pro přežití (Shaw et al. 2012, 1, 2).

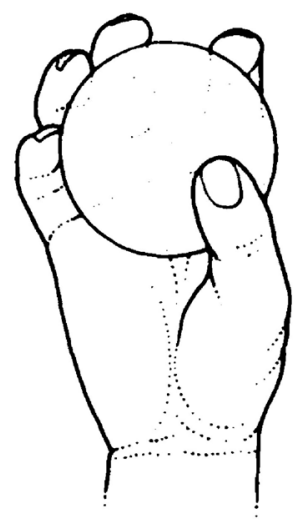

A

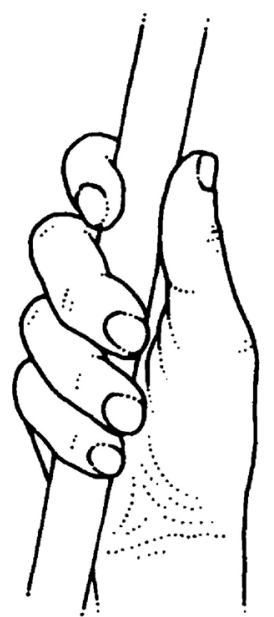

B
Obr. 2. A - příčný úchop, B - šikmý úchop. Upraveno podle: Aiello, Dean 1990,372 .

Nejběžnějšími nástroji moustérienu jsou drasadla a škrabadla (úštěpové nástroje $s$ retuší), která se používají k seškrabávání šlach a srsti ze zvířecí kůže, nicméně frekvence zpracování kůže u neandertálců není zcela jasná. I přesto je pravděpodobnější, že morfologie pažní kosti je odrazem právě této činnosti, protože štípání nástrojů je pro zkušeného jedince jednodušší, nepůsobí velkou biomechanickou zátěž a je tedy nepravděpodobné, že by mohlo mít za následek změny morfologie kostí (Shaw et al. 2012, 2).

\section{Manuální zručnost}

Ruka neandertálců je mimo jiné charakteristická tvarem prvního karpometakarpálního kloubu. Kloubní povrch kosti mnohohranné větší (os trapezium) je u některých jedinců cylindrický (konvexní v radioulnárním směru a rovný v dorzopalmárním směru). U jedince La Chapelle-aux-Saints 1 byl však pozorován kloubní povrch kondylární, tedy v obou směrech konvexní (Aiello, Dean 1990, 394). Morfologie prvního karpometakarpálního kloubu je základem pro přesný úchop. Vzhledem k tomu, že moderní lidé mají tento kloub sedlovitého tvaru, lze ve schopnosti přesného úchopu očekávat rozdíly. Ty však nemusí být významné, protože morfologie ruky neandertálců spadá do rozsahu variace moderních lidí. Rozdíly mezi moderními lidmi a neandertálci v manipulaci rukou nespočívaly ve zručnosti, ale v síle úchopu a schopnosti odolávat silám vynaloženým v určité pozici ruky při úchopu. Morfologie ruky neandertálců je vhodná pro silný př́ičný úchop (např́ílad valounu, obr. $2 \mathrm{~A}$ ), kdežto ruka moderního člověka lépe umožňuje šikmý úchop (používaný například při držení rukojeti nějakého nástroje, obr. 2 B, Churchill 2001, 2953). 


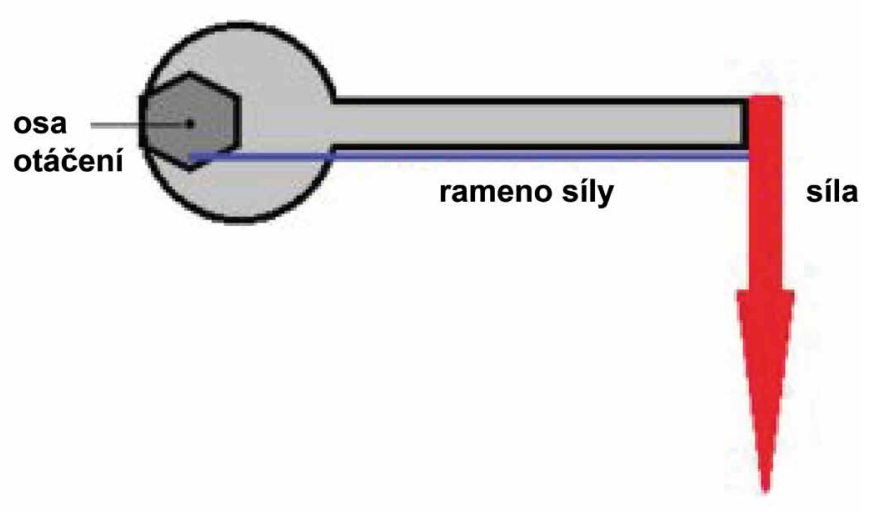

Obr. 3. Rameno síly (upraveno podle: https://physicsabout.com/torque/)

Neandertálci, stejně jako moderní lidé, zasazovali vyrobené nástroje do rukojetí. Rozdíl mezi těmito skupinami tedy nebyl ve schopnosti výroby kombinovaných zbraní, ale v technologii, která k tomu byla užita. Rozdílná mohla být také frekvence této činnosti. Vzhledem $\mathrm{k}$ účinnosti svalů používaných při výrobě nástrojů, může rozdíl v technologii odrážet rozdíly $\mathrm{v}$ síle potřebné k této činnosti. Avšak bez přímých důkazů nelze důležitost a frekvenci výroby nástrojů spolehlivě zhodnotit (Churchill 2001, 2954).

Existují nepřímé linie, které naznačují, že zasazování nástrojů do rukojeti hrálo u moderního člověka důležitou roli. Podobně je to i u neandertálců, kde je však výrazný rozdíl v míře retuše, která se u nástrojů zasazených do rukojeti očekává, protože obvykle bývá považováno za jednodušší opravit retuši na okraji nástroje než jej celý vyměnit. U neandertálců se retuše objevuje ve $20 \%$, zatímco u moderního člověka je to v $64 \%$. Nicméně zdá se, že u moderních lidí byla retuše využívaná spíše k tvarování než k opravám (Churchill 2001, 2954). Z uvedených poznatků nelze jednoznačně říci, že by morfologie ruky vhodnější pro šikmý úchop a větší míra retuše přinášely moderním lidem výhodu nad neandertálci. Pravděpodobněji jsou tyto rozdíly součástí nově vznikajícího adaptivního systému moderního člověka, který zahrnuje větší využívání specifických nástrojů, složitější nástroje, logistické plánování shánění potravy a také větší sociální zdatnost (Churchill 2001, 2954, 2955).

\section{POHYB DOLNÍCH KONČETIN}

\section{Pohyb v kolenním a hlezenním kloubu}

Morfologie kolenního a hlezenního kloubu neandertálců se od moderních lidí v několika znacích liší. K těmto znakům patři například silnější čéška, více vystupující drsnatina na proximálním konci holenní kosti (tuberositas tibiae) nebo delší patní kost. Funkční interpretace těchto odlišností je předmětem výzkumů.

\section{a) kolenní kloub}

Rameno síly (obr. 3) je definováno jako kolmá vzdálenost přímky, na které leží síla, od osy otáčení. Čím je rameno síly větší, tím je větší účinnost svalu (Reichl 2006 - 2015). Ramena sil kolenního kloubu jsou u neandertálců všeobecně vyšší než u moderních lidí. Je to dáno větší předozadní šířkou čéšky (absolutně i relativně) a také dorzálním posunem kondylů holenní kosti. Velikost rozdílu však závisí na úhlu, ve kterém se kolenní kloub nachází. V rozsahu úhlů používaných při pohybu $\left(0^{\circ}-70^{\circ}\right.$ flexe) je rozdíl $8 \%$, při více flexním postavení kloubu $\left(>70^{\circ}\right)$ je rozdíl pouze $2 \%$ (Miller, Gross 1998,357 ). Posuzovanými svaly byly $\mathrm{v}$ tomto př́padě $m$. rectus femoris, $m$. vastus medialis, $m$. vastus intermedius a $m$. vastus lateralis. Jedná se tedy o čtyřhlavý sval stehenní ( $m$. quadriceps femoris), který je díky své hlavní funkci, extenzi kolene, důležitý při udržování vzpřímené postavy a také při chůzi. Neandertálci tak měli díky jeho větší síle v těchto parametrech oproti moderním lidem výhodu.

Pro spočtení těchto rozdílů byla použita robustnost čéšky, na kterou se $m$. quadriceps femoris upíná. Vzhledem $\mathrm{k}$ tomu, že čéška neandertálců je o $22 \%$ silnější než čéška moderních lidí a nárůst velikosti ramena síly je $8 \%$ (potažmo $2 \%$ ), vztah morfologie kostí a účinnosti svalu je $\mathrm{v}$ tomto př́padě neproporcionální (Miller, Gross 1998, 359).

\section{b) hlezenní kloub}

Pro spočtení ramen sil svalů hlezenního kloubu byly vytvořeny dva modely:

1) Neandertal (13\%): indexy kostí hlezenního kloubu byly u neandertálců v průměru o $13 \%$ vyšší než u moderního člověka

2) Neandertal (30 \%): indexy kostí byly v průměru o 30 \% vyšší (Miller, Gross 1998, 356).

U obou těchto modelů byla ramena sil svalů hlezenního kloubu vyšší než u moderního člověka. Největší velikost byla zaznamenána u modelu Neandertal (30 \%). Podobně jako u kolenního kloubu byl i zde rozdíl v nárůstu velikosti ramena síly při úhlech kloubu používaných v lokomoci a při plantární flexi, rozdíl byl ale méně výrazný. Úhly využívané při lokomoci jsou od $-20^{\circ}$ (směrem k plantární flexi) do $+20^{\circ}$ (směrem $\mathrm{k}$ dorzální flexi). Při těchto úhlech byl průměrný nárůst velikosti ramena síly u modelu Neandertal (13\%) o 22 \% a u modelu Neandertal (30\%) o $41 \%$. Při větší plantární flexi byly rozdíly $21 \%$ u modelu Neandertal (13\%) a 39\% u modelu Neandertal (30\%). Posuzovanými svaly byly $m$. gastrocnemius a $m$. soleus. Tyto svaly tvoří $m$. triceps surae, flexor nohy, který je důležitý při chůzi a běhu (Miller, Gross 1998, 357). Stejně jako v předchozím př́padě, ani u hlezenního kloubu nelze $\mathrm{z}$ rozdílu ve velikosti kostí přesně určit rozdíl ve velikosti ramen síly. Na rozdíl $13 \%$ ve velikosti indexů kostí připadal rozdíl $22 \%$ ve velikosti ramen sil (u plantární flexe $21 \%$ ) a pro $30 \%$ rozdíl ve velikosti indexů byl $41 \%$ (při plantární flexi 39\%) rozdíl ve velikosti ramen sil (Miller, Gross 1998, 359).

\section{Chůze}

Energetická náročnost chůze je ovlivněna stejnými vlastnostmi jako u neandertálců tolik diskutovaná adaptace na chladné 
Energetická náročnost chůze + náročnost vzpřímeného držení těla a celkový metabolismus

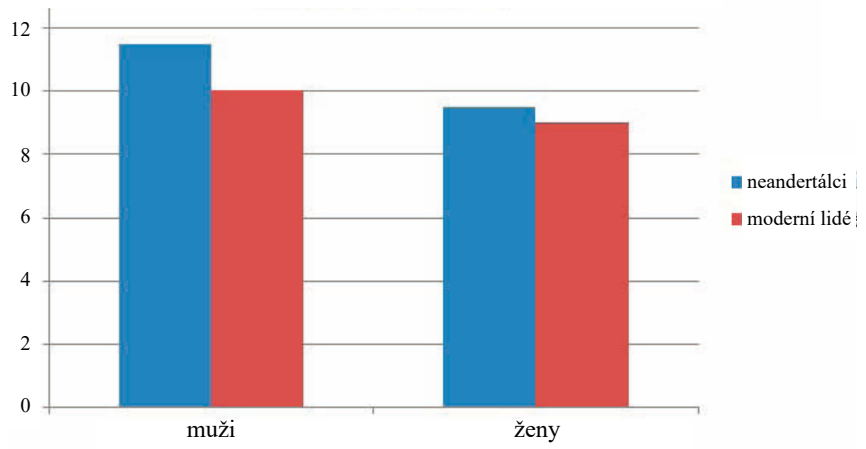

Obr. 4. Celkové náklady na chůzi (podle: Hora, Sládek 2014a)

podnebí, tedy např́klad vyšší tělesná hmotnost, krátké končetiny nebo širší hrudník. Vzhledem k tomu, že většinu energie vydané na pohyb spotřebují svaly, které musí odolat gravitaci, lze předpokládat, že neandertálci se svojí větší tělesnou hmotností a robustnější stavbou těla budou mít spotřebu energie vysokou (Hora, Sládek 2014a, 20). Jelikož měli neandertálci kratší dolní končetiny než moderní člověk, předpokládá se, že jejich chůze byla méně účinná, krátké končetiny totiž mohou mít za následek menší délku kroku, tudíž by na překonání dané vzdálenosti potřebovali více kroků a tím pádem i více energie (De Winter 2011). Studie, které berou v úvahu hornatý terén, ve kterém se neandertálci vyskytovali, však přináší mírně odlišné výsledky. Bylo zjištěno, že chůze na nerovném terénu nebyla pro neandertálce energeticky náročnější než pro moderního člověka. Analýzy, které vlastnosti terénu nezohledňují, ukazují, že větší délka dolních končetin snižuje náklady na chůzi ve všech rychlostech (Steudel - Numbers, Tilkens 2004, 101). Toto však platí pouze tehdy, je-li spolu $s$ větší délkou dolních končetin zvětšená také účinnost svalů kolenního kloubu (Hora, Sládek 2014a, 29). U neandertálců se však větší účinnost svalů vyskytuje spolu s kratšími končetinami, pro úplné posouzení těchto faktorů a jejich vlivu na náročnost chůze je tedy třeba dalších studií.

Kromě délky dolních končetin a tělesné hmotnosti jsou náklady na chůzi ovlivněny také morfologií kloubů, především jejich robustností. Robustnější klouby neandertálců poskytují svalům větší mechanickou výhodu - pohyb lze provést $s$ vyvinutím menší síly a tím i s menší spotřebou energie. K faktorům určujícím mechanickou výhodu kolenního a hlezenního kloubu patř́ účinnost svalů, ve které se neandertálci od moderních lidí výrazně liší. Co se týče kolenního kloubu, rameno síly čtyřhlavého svalu stehenního ( $m$. quadriceps femoris) je větší díky zakřivení stehenní kosti a robustní čéšce. Mechanická výhoda tohoto kloubu je tedy v porovnání s moderními lidmi větší. U hlezenního kloubu se vzhledem $\mathrm{k}$ dlouhé patní kosti předpokládají větší ramena sil plantárních flexorů. Je tedy možné, že dolní končetiny neandertálců představují účinný mechanismus, který, co se týče nákladů na chůzi, vyváží vliv velikosti a hmotnosti jejich těla (Hora, Sládek 2014a, 20).
Energetická náročnost chůze samotné

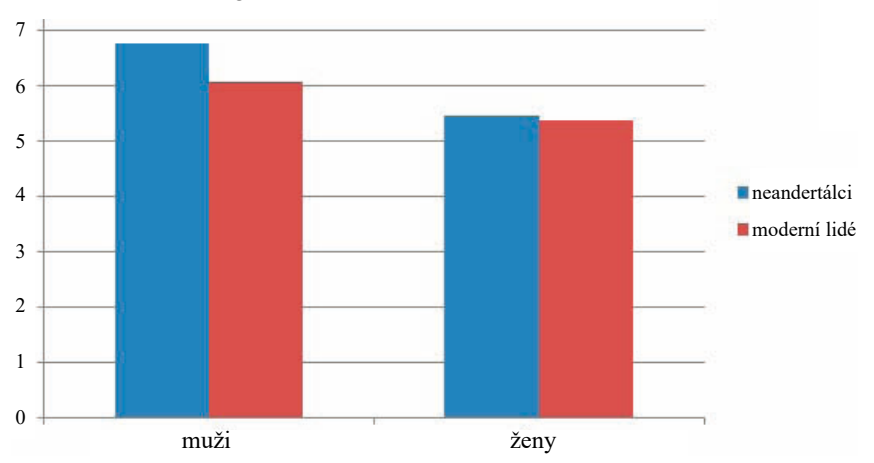

Obr. 5. Náklady pouze na chůzi (podle Hora, Sládek 2014a)

Celková energie potřebná $\mathrm{k}$ překonání dané vzdálenosti zahrnuje kromě nákladů na chůzi také náročnost vzpřímeného držení těla a celkový metabolismus. Analýzy dělané pro obě pohlaví dohromady uvádí, že tyto celkové náklady byly u neandertálců o 30 \% vyšší než u moderních lidí (Steudel - Numbers, Tilkens 2004, 103; Hora, Sládek 2014a, 20). Rozdělení mužů a žen v pozdějších studiích přináší odlišné výsledky. Co se týče mužského pohlaví, celkové náklady na chůzi byly pro neandertálce o 9 - $14 \%$ vyšší než pro moderního člověka. Pro ženské pohlaví to bylo pouze o 1 - 6\% více (Obr. 4, Hora, Sládek 2014a, 24). Náklady pouze na chůzi, tedy bez náročnosti vzpřímeného držení těla a celkového metabolismu, jsou pro neandertálce vyšší o 8 - 12\% u mužů a o méně než $2 \%$ u žen (Obr. 5, Hora, Sládek 2014a, 24). Po odečtení nákladů na vzpřímené držení těla a celkový metabolismus se rozdíl mezi neandertálci a moderními lidmi u mužů snížil a u žen téměř vymizel. Je tedy zřejmé, že tyto dva faktory mají pro muže malý vliv na energetickou náročnost chůze, avšak u žen představují zásadní příčinu rozdílu. U mužů jsou tak rozdíly pravděpodobně způsobeny jinými faktory, například tělesnou hmotností nebo proporcemi dolních končetin (Hora, Sládek 2014a, 24).

\section{Běh}

Ačkoliv se energetická náročnost chůze neandertálců a moderních lidí příliš nelišila, u běhu byly rozdíly podstatnější. Byla zjištěna silná korelace mezi délkou hrbolu patní kosti (tuber calcanei) a energetickou náročností běhu. Důležitou roli při snižování náročnosti běhu tak hraje Achillova šlacha, která se při každém kroku ukládá a poté uvolňuje energii a na zmiňovaný tuber calcanei se upíná. U jedinců, kteří mají tuber calcanei krátký, se při pohybu Achillova šlacha více stáhne a převede se tak více kinetické energie do energie pružnosti použité při uvolnění šlachy. Tím se náklady na běh snižují (Raichlen et al. 2011, 304). Neandertálci mají ale tuber calcanei (i patní kost celkově) delší, což popisovanou schopnost Achillovy šlachy omezuje a existuje tak předpoklad větší spotřeby energie při jejich běhu (Hora, Sládek 2014b, 158; Raichlen et al. 2011, 300). Tento předpoklad byl v analýze potvrzen. Při porovnání s moderním člověkem bylo zjištěno, že 
energetická náročnost běhu neandertálců byla o $11,4 \%$ vyšší (Raichlen et al., 2011, s. 303). Výsledky však nemusí být s jistotou správné, protože porovnávaná data neandertálců byla mimo rozsah dat moderního člověka a analýzy v těchto př́padech vykazují větší množství chyb (Raichlen et al. 2011, 304). I přesto, že běh je délkou tuber calcanei a funkcí Achillovy šlachy významně ovlivněn, na chůzi tyto faktory vliv nemají (Raichlen et al. 2011, 304).

\section{ZÁVĚR}

Jedinečná anatomie neandertálců zahrnuje zakřivenou stehenní a vřetenní kost, kratší předloktí a bérce, objemný hrudník nebo velký přední otvor nosní dutiny (apertura piriformis). Aktivita neandertálců se odráží v celkové robustnosti jejich skeletu. Morfologie jejich dolních končetin bývá považována za přizpo̊sobenou na pohyb v kopcovitém terénu, naproti tomu v rovinách mohli být neandertálci pomalejší.

Bederní lordóza neandertálců vybočuje ze všeobecného trendu zvětšujícího se lordotického zakřivení během vývoje vzpřímené postavy a bipedie. Zkosení těl bederních obratlů je ventrální, což způsobuje rovnou až kyfoticky zakřivenou bederní část páteře. Lordotický úhel neandertálců je tedy menší než u moderních lidí. Vliv popisované morfologie na lokomoci je nejasný.

Výzkumy pohybu horních končetin se zabývaly především schopností házení, škrábání a manuální zručností. Bylo zjištěno, že je pravděpodobné, že házení nebylo činností pro neandertálce obvyklou, na rozdíl od škrábání, které bylo pro neandertálce důležité (Shaw et al. 2012, 1,2). Co se týče manuální zručnosti, rozdíly mezi neandertálci a moderními lidmi spočívají především v síle úchopu, nikoliv v samotné zručnosti. Bylo také zjištěno, že morfologie ruky neandertálců je vhodnější $\mathrm{k}$ prŕíčnému úchopu. $\mathrm{Z}$ dostupných informací však nelze říci, zda odlišný typ úchopu přinášel moderním lidem nějakou výhodu oproti neandertálcům (Churchill, 2001, 2953, 2954).

Analýzy pohybu dolních končetin se zaměřily hlavně na chůzi a běh. Při využívání bipedního pohybu je efektivita chůze či běhu velmi důležitá. Energetická náročnost chůze je ovlivněna několika faktory, ke kterým patří např́klad tělesná hmotnost, délka dolních končetin nebo objem hrudníku. Dle těchto parametrů by pro neandertálce měla být chůze energeticky náročnější. Robustnější klouby však svalům neandertálců poskytují větší mechanickou výhodu a negativní vliv hmotnosti nebo délky dolních končetin by tak mohly vyvážit. Náklady na chůzi jsou ale ovlivněny také náročností vzpř́imené chůze a metabolismem. Po započtení těchto parametrů se ukázalo, že mají vliv spíše na náročnost chůze žen, nikoliv mužů. Jednotlivé studie se také neshodují na velikosti rozdílu v náročnosti chůze mezi neandertálci a moderními lidmi, shodují se však na tom, že pro neandertálce byly celkové náklady na chůzi mírně vyšší (Hora, Sládek 2014a, 20 - 29; Steudel Numbers, Tilkens 2004, 101 - 103).

Co se týče běhu, jeho energetická náročnost je ovlivněna pře- devším délkou hrbolu patní kosti (tuber calcanei) a na něj se upínající Achillovou šlachou. Větší délka hrbolu patní kosti neandertálců pravděpodobně omezuje činnost Achillovy šlachy a tím se spotřeba energie při běhu zvyšuje. Rozdíl v energetické náročnosti běhu mezi moderními lidmi a neandertálci by měl být větší, než tomu bylo u chưze. Sami autoři studie (Raichlen et al., 2011) však připouští, že výsledky nemusí být správné, protože srovnávaná data neandertálců se nacházela mimo rozsah dat moderního člověka.

Vzhledem k zachovalosti kostí a jejich změnám je zřejmé, že analýza morfologie neandertálců, její vliv na lokomoci a srovnání jejich lokomoce s moderními lidmi není jednoduché. $\mathrm{Na}$ výsledcích studií se mnohdy projevuje nedostatek vhodného materiálu. Řada studií však byla po objevení nových nálezů zopakována a rozšířena. Tyto nové analýzy v některých případech potvrzují výsledky předchozích studií, jindy dřívějším závěrům odporují nebo je upravují či zpřesňují.

Je zřejmé, že v lokomoci neandertálců a moderních lidí existují rozdíly. Neandertálci byli zaměření spíše na chůzi než běh, který pro ně byl energeticky náročný. Dle morfologie pažní kosti pro ně bylo důležité zpracování kůže a s tím související pohyby rukou (škrábání). V manuální zručnosti se moderním lidem vyrovnali. Lokomoce samotná pravděpodobně nebyla prř́činou zániku neandertálců, nebot i přes veškeré rozdíly $\mathrm{z}$ ní nevyplývala významná nevýhoda oproti moderním lidem. K jejich vyhynutí zajisté prrispělo více faktorů, které působily společně.

\section{PODĚKOVÁNÍ}

Na tomto místě bych ráda poděkovala doc. Mgr. Sandře Sázelové, $\mathrm{PhD}$. za cenné rady a připomínky. Dále poděkování patří prof. PhDr. Jiřímu Svobodovi, DrSc., vedoucímu mojí diplomové práce, ze které tento článek vychází.

Tento článek vznikl za podpory specifického vysokoškolského výzkumu č. MUNI/A/1268/2017 (Nové postupy při analýze osteologického materiálu humánního a archeozoologického původu), kterou poskytlo MŠMT.

\section{LITERATURA}

Aiello, Leslie - Dean, Christopher (1990): An Introduction to Human Evolutionary Anatomy. London: Academic Press.

Been, Ella - Gómez-Olivencia, Asier - Kramer, Patricia A. (2012): Lumbar lordosis of Extinct Hominins. American Journal of Physical Anthropology, 147(1), 64-77. https://doi.org/10.1002/ajpa.21633

Been, Ella - Gómez-Olivencia, Asier - Kramer, Patricia A. - Balash, Alon (2017): 3D Reconstruction of Spinal Posture of the Kebara 2 Neanderthal. In: Marom A., Hovers E. (eds) Human Paleontology and Prehistory. Vertebrate Paleobiology and Paleoanthropology. Springer, Cham. https://doi.org/10.1007/978-3-319-46646-0_18

Churchill, Steven E. (2001): Hand morphology, manipulation, and tool use in Neandertals and early modern humans of the Near East. Proceedings of the National Academy of Sciences, 98(6), 2953-2955. https://doi. org/10.1073/pnas.061032198

Churchill, Steven E. - Rhodes, Jill A. (2006): How Strong were the Neanderthals? Leverage and Muscularity at the Shoulder and Elbow in Mousterian Foragers. Periodicum Biologorum, 108(4), 457-470. 
De Winter, Gunnar (2011): The Short Legs of the Neanderthal. (online). http://www.science20.com/curious_cub/short_legs_neanderthal-84035

Di Vincenzo, Fabio - Churchill, Steven E. - Manzi, Giorgio (2012): The Vindija Neanderthal scapular glenoid fossa: Comparative shape analysis suggests evo-devo changes among Neanderthals. Journal of Human Evolution, 62(2), 274-285. https://doi.org/10.1016/j.jhevol.2011.11.010

Hora, Martin - Sládek, Vladimír (2014a): Influence of lower limb configuration on walking cost in Late Pleistocene humans. Journal of Human Evolution, 67, 19-32. https://doi.org/10.1016/j.jhevol.2013.09.011

Hora, Martin - Sládek, Vladimír (2014b): Efektivita chůze a běhu v evoluci člověka. Živa, 4, 156-158. (online). http://www.ziva.avcr.cz/files/ziva/ pdf/efektivita-chuze-a-behu-v-evoluci-cloveka.pdf

Miller, Jeffrey A. - Gross, M. Melissa (1998): Locomotor advantages of Neandertal skeletal morphology at the knee and ankle. Journal of Biomechanics, 31, 355-361. https://doi.org/10.1016/S0021-9290(98)00031-1

Niewoehner, Wesley A. - Bergstrom, Aaron - Eichele, Derrick - Zuroff, Melisa - Clark, Jefferey T. (2003): Digital analysis: Manual dexterity in Neanderthals. Nature, 422, 395-395. https://doi.org/10.1038/422395a

Raichlen, David A. - Armstrong, Hunter - Lieberman, Daniel E. (2011): Calcaneus length determines running economy: Implications for endurance running performance in modern humans and Neandertals. Journal of Human Evolution,60(3), 299-308. https://doi.org/10.1016/j.jhevol.2010.11.00

Reichl, Jaroslav (@ 2006 - 2015). Moment síly vzhledem k ose otáčení. Encyklopedie fyziky. (online). http://fyzika.jreichl.com/main.article/view/84moment-sily-vzhledem-k-ose-otaceni

Shaw, Colin N. - Hofmann, Cory L. - Petraglia, Michael D. - Stock, Jay T. Gottschall, Jinger S. (2012): Neandertal Humeri May Reflect Adaptation to Scraping Tasks, but Not Spear Thrusting. PLoS ONE, 7(7): e40349. https://doi.org/10.1371/journal.pone.0040349
Sparrey, Carolyn J. - Bailey, Jeannie F. - Safaee, Michael - Clark, Aaron J. - Lafage, Virginie - Schwab, Frank - Smith, Justin S. - Ames, Christopher P. (2014): Etiology of lumbar lordosis and its pathophysiology: a review of the evolution of lumbar lordosis, and the mechanics and biology of lumbar degeneration. Neurosurg focus, 36(5), E1. https://doi. org/10.3171/2014.1.FOCUS13551

Spoor, Fred - Hublin, Jean-Jacgues - Braun, Marc - Zonneveld, Frans (2003): The bony labyrinth of the Neanderthals . Journal of Human Evolution, 44(2), 141-165. https://doi.org/10.1016/S0047-2484(02)00166-5

Steudel-Numbers, Karen L. - Tilkens, Michael J. (2004): The effect of lower limb length on the energetic cost of locomotion: implications for fossil hominins. Journal of Human Evolution, 47(1-2), 95-109. https://doi.org/10.1016/j.jhevol.2004.06.002

Trinkaus, Erik (1983): The Shanidar Neanderthals. New York: Academic Press. Vančata, Václav (2003): Paleoantropologie - přehled fylogeneze člověka a jeho předků. Brno: Akademické nakladatelství CERM. Panorama biologické a sociokulturní antropologie $13212 \mathrm{~s}$.

https://physicsabout.com/torque/

\section{AUTORKA}

Michaela Káčerková, roz. Turková $\left({ }^{*} 1991\right.$, Brno), studentka doktorského studijního programu Antropologie. Od začátku studia se zabývá kosterní antropologií a paleoantropologií. Zaměřuje se především na neandertálce a jejich porovnání s moderním člověkem.

Kontakt: Mgr. Michaela Káčerková, Ústav antropologie, Př́rodovědecká fakulta, Masarykova univerzita, Kotlářská 267/2, 61137 Brno. email: 371337@mail.muni.cz 
